\title{
Adaptation Research on the Flow of College Teachers and Social Economic Development in Xinjiang
}

\author{
Qingbo Zhang \\ Normal School, Shihezi University \\ Shihezi 832003, China \\ E-mail: zhangqingyan541@163.com \\ Qiong Jia \\ Normal School, Shihezi University \\ Shihezi 832003, China
}

\begin{abstract}
The flow of college teachers is an important part of college staff construction. The demands for higher education by Xinjiang's social economic development go to the flow of college teachers indirectly. Based on an analysis on the basic condition of Xinjiang's social and economic development as well as a retrospect on the policies on the harmonious development of higher education and regional economy there, this paper puts forward some strategies on how to adapt the flow of college teachers to the social economic development in the new situation.
\end{abstract}

Keywords: Xinjiang's social and economic development, Policy efforts, Flow of college teachers

\section{The Basic Condition of Xinjiang's Social Economic Development}

\subsection{Economy to Develop Steadily}

In 2008, Xinjiang's social economy achieved steady development, its GDP reaching 420,341,000,000 yuan, up 11.0\% over that of the previous year, and maintaining six successive years' double-digit growth (Statistical Communique on the National Economy and Social Development of Xinjiang in 2008). Such a constant and rapid economic development has offered a solid economic basis as well as strong demands for educational development in the first 20 years of the $21^{\text {st }}$ century. Therefore, in order to upgrade its national economy and social development, Xinjiang is expected to take advantage of the favorable macro environment for economic development to effectively implement the strategy of developing Xinjiang by relying on science, technology and talents, to further accelerate educational development, to improve the quality of college staff construction and therefore to improve local people's education as well as the rapid growth of local economy.

\subsection{Industrial Structure to be Adjusted and Upgraded}

The first 20 years of the $21^{\text {st }}$ century will witness a speed-up in the adjustment and upgrade of China's industrial structure. Lying in the medium term of industrialization, China still relies on the secondary industry as its main drive for economic development in a long run. Seen from the variation of GDP composition of three industries, by 2020 , the primary industry will be lowered to about $7 \%$; the second industry is mainly devoted to structure adjustment and upgrade, maintaining about $50 \%$ of the total; the tertiary industry will grow at a higher speed, reaching $10 \%$ of the total, hence the department with the most remarkable variation in industrial structure of all.

Ever since the reform and opening up, the conversion process of Xinjiang's economic structure has lagged far behind that of the east as well as the whole nation, hence having a low level of industrial structure, poor comparative benefit, especially laggard industrialized development. In 2008, the ratio of the three industries in Xinjiang was 16.4: 49.7: 33.9; its GNP per capita (19893 yuan) grew by $8.9 \%$.

\subsection{Urbanization to be Further Strengthened}

With the speed-up in the transfer of rural labor force, about 300,000,000 to 400,000,000 will enter urban areas from 
2010 to 2020 (Center for China Study,2003). Urbanization will surely bring about mobility and redistribution of population among different areas and occupations. As the basic channel to improve employed staff's cultural and technical qualities as well as to improve the quality of human resources, education and training are critical in promoting labor force mobility.

According to the data from the fifth census of China in 2000, the urbanization rate in Xinjiang was $33.82 \%, 2.33 \%$ lower than the national one; in 2002, Xinjiang's urbanization rate was $33.84 \%, 5.3 \%$ lower than the national one. It is obvious that its urbanization process has been laggard behind the national level and the disparity between the two has even been increasingly wider. Generally, when the urbanization rate of a region reaches $30-50 \%$, its urbanization development enters the speed-up stage, calling for mixed education (National Center for Education Development Research, 2005). Currently, Xinjiang's higher education distribution and structure is in constant improvement. In terms of the current educational development, universities and colleges should be established in the cities with a population over 1,000,000 or with long cultural history in order to conform to their economic development and social stability.

\section{Demands for Xinjiang's Higher Education by its Social Economic Development Strategy}

\subsection{The Relationship between Higher Education and Regional Economy Development}

1). Higher Education is the source of power for the development of regional economy. The coordination of higher education and regional development can promote steady, constant and harmonious social and economic development. It was found in Zhaozhang Ren's research on the relativity of economic growth and higher education in Guangdong that there was strong relativity between the two. The correlation coefficient between the number of college graduates and GDP per capita as well as that between the number of college undergraduates and GDP per capita in Guangdong were 0.9159 and 0.9272 respectively ( $\mathrm{Li}, 1999$ ). According to Hongbin Zhao's research on the distribution of Chinese universities, regional GDP per capita at the provincial level had a correlation coefficient over 0.8 with the number of college graduates and undergraduates (Zhao, 2007). In addition, based on the material from Statistical Survey of China in 2004, Yimin Yang ranked GDP per capita and the number of college students out of every ten thousand people and calculated the difference of degree between the two. It turned out that there were 10 with a harmony between higher education and economic development and 5 with a fundamental harmonious development; the eastern area (except for Liaoning) had faster development in economy than in higher education while the middle and western area went to the opposite (Yang, 2006).

2). Sustainable economic development and the rapid conversion of economic structure require educational development to fulfill constantly increasing and varying technical demands. Economic growth is mainly determined by five elements including population growth, the increased amount of capital deposited, the improvement of labor force quality, the improvement of resource allocation efficiency and technical advance (Hu, 2001). It has been long that rapid capital accumulation is a main factor to promote China's economic advance. Since labor force will stop growing after 2010, this advantage will fail to support economic growth any longer. Therefore, China has to accelerate its conversion from the development pattern driven by capital to that driven by knowledge and education, from the growth pattern based on accumulation to the accumulation pattern based on technical changes and human resources investment.

The smooth implementation of China's "Western Development"project and the issuance of No.32 File have shown the great importance attached by central government to Xinjiang's social economic development. Xinjiang is expected to seize this historic opportunity to further improve the scale benefit of its higher education, the positive effects of higher teachers' scale and quality on social economy and therefore to further exert the supportive effects of Xinjiang's higher education on its economy.

\subsection{Policy Efforts for the Harmonious Development of Xinjiang's Higher Education and Regional Economy}

The central and the autonomous governments have laid down corresponding policies in order to promote the effective development of Xinjiang's social economy, to conform to the demands by the knowledge economy era and to create harmonious development of Xinjiang's higher education and social economy.

It is pointed out clearly in The Eleventh Five-Year Plan for Xinjiang's National Economy and Social Development to implement the strategy of developing Xinjiang by relying on science, education and talents. As a result, greater efforts should be made to improve the quality of higher education and to further optimize the structure of higher education oriented by the market, to implement "Aid-Tibet Disciplinary Construction Plan" as well as "The Plan to Support Universities in Western China", to encourage and attract high-level talents to teach in Xinjiang's universities and to cultivate an array of advanced leaders in different specialties. As for the construction of talents, the principle of sticking to man-orientation and the Communist Party's authority over talents should be followed and the demands by Xinjiang's economic and social development should be based on to cultivate practical talents in multi forms. Through cultivation, training and communication, talent staff with sufficient total amount, reasonable structure and higher overall quality should be constructed by sticking to the combination of increasing the number and the quality of talents.

As is required in The Eleventh Five-Year Plan for Xinjiang's Educational Development, the scientific outlook of 
development should play a leading role in education. Education should be given priority to to implement the strategy of developing education by relying on science, education and talents. In addition, talent cultivation should be based on and students should be regarded as the main body in education; talents should be based on and teachers should be the main body in school running. It is estimated that Xinjiang's education will have overall approached the level of moderately developing provinces and cities, the construction of some key specialties organized by universities there will have approached or reached the advanced level and the gross enrollment rate of higher education will reach about $30 \%$ by 2015.

\section{The Relationship between Xinjiang's Social Economic Development and the Quality of Teaching Staff in its Universities}

Budgetary appropriation is the main channel for Chinese universities to get capital currently. Since 1985, according to Decisions on Educational System Reform by the Central Committee of the Communist Party of China, China has conducted great reforms on its educational system, in which grading school running and administration is implemented and the money for higher education should be raised at the levels of central government, provinces and central cities. Due to the imbalance among different areas in geographical conditions, economic and cultural development, there are great differences in raising money for education ( $\mathrm{Lu}, 1999)$.

In addition, the development of regional economy is closely related to the construction of college staff. A society with developed economy tends to have higher educational input and social economic development has strong demands for that of higher education. In addition, open ideas are beneficial for researches in universities as well as their independent development, drive by which college staff will be surely improved. As a result, these universities and such a society will attract more teachers and their sense of competition will be stronger, hence promoting a reasonable and orderly flow of college teachers.

The effect of government investment in college staff and the relationship between college staff quality and social economic development are shown as follows:

Xinjiang's social economic development has obviously lagged behind the southeastern coastal area. In 2007, its GDP per capita was 15000 yuan, ranking the $14^{\text {th }}$ of the whole nation; the average length of education was 7.34 years, ranking the $12^{\text {th }}$ of the whole nation. During the same period, Beijing had GDP per capita of 50467 yuan, ranking the $2^{\text {nd }}$ of the nation; its average length of education was 10.95 years, ranking the top (China Human Resources R\&D Institute, 2008). Of course, the construction of basic facilities in Xinjiang's universities cannot be compared with that of the eastern area. Although the ratio of teachers and students in Xinjiang's universities in 2007 was 14.33, which satisfied the demands of the nation, the scale of its universities needs to be enlarged due to the small scale of its higher education and the increasing demands for higher education nowadays.

\section{Strategies for the Flow of College Teachers Based on Xinjiang's Middle and Long-term Development Strategies}

\subsection{The Influences of Changes in Xinjiang's School Age Population on the Flow of College Teachers}

The scale and the proportion of school age population will be constantly lowered, which will be one important feature of China's population conversion in the future 20 years. It is estimated that the total school age population in China will be lowered by $8.8 \%$ by 2010 compared with the current data and its proportion in the total population will be lowered from $28.7 \%$ to $24.3 \%$ compared with 2000 ; it will be lowered to $20.9 \%$ up to 2020 .

The decline of both the scale and the proportion of school age population in the future 20 years will exert a series of profound influences on the development of Chinese economic society and education. The decline of school age population scale will lessen the huge pressure from the expansion of educational scale objectively, including improving school running conditions and lessening the resource input pressure in order to improve educational quality.

There will be a decline in Xinjiang's school age population in the future 5 to 10 years (The Eleventh Five-Year Plan for Xinjiang's Educational Development). In spite of the increasing demands for higher education in Xinjiang in the short term, the scale of higher education and college teachers must be controlled to have reform in higher education's connotation, hence helping higher education to step into a new phase centering on quality improvement (National Center for Education Development Research, 2008). Therefore, great efforts should be made to reasonably control the scale of universities, to improve the academic quality of college teachers, to keep an open flow of college teachers and to dismiss those unqualified teachers while attracting advanced ones.

\subsection{The Influences of Xinjiang's Industrial Structure Adjustment on the Flow of College Teachers}

The development of regional economy is closely related to higher education resources in that regional economy calls for local higher education to offer intellectual resources and technical support and higher education must be in conformity to the demands by regional economy. Accordingly, some adjustments should be made in specialty setting or research directions and new-style talents required by new industries should be cultivated according to the upgrade and 
adjustment of regional industrial structure. Reflected in the flow of college teachers, it will involve matching the introduction, cultivation and maintenance of college teachers with the orientation of universities as well as the development of regional economy.

Similarly, new-style college teachers are demanded in order to adjust specialties or research directions as well as to cultivate new-style talents in conformity to new industries. During the flow of college teachers, the introduction, cultivation and maintenance of them should match with Xinjiang's economic development since only those universities serving regional economy are successful ones.

\section{References}

(2005). Statistical Survey of China. China Statistical Press.

Center for China Study by Chinese Academy of Science and Tsinghua University. (2003). National Realities and Development: Research Report on Beijing in the Eleventh Five-Year Plan of China, p152.

China Human Resources R\&D Institute. (2008). Report on China Human Resources Development in 2008: the Condition of China's Human Capital. Beijing: China Development Press, (11):158.

$\mathrm{Hu}$, Angang. (2001). Knowledge and Development: New Strategy for the $21^{\text {st }}$ Century. Beijing University, p231.

Li, Chao \& Li, Hongchang. (1999). Analysis and Prediction on Guangdong's Economic Conditions in 1999. Guangdong People's Publishing House.

Lu, Xiang. (1999). On the Regional Differences in China's Economic Social Development and Strategies for its Higher Education Development. East China Economic Development, (5):23-25.

National Center for Education Development Research. (2005). Green Book of China's Education: Annual Analysis Report on China's Educational Policies. Beijing: Science Education Publishing Company, p12.

National Center for Education Development Research. (2008). Green Book of China's Education: Annual Analysis Report on China's Educational Policies. Beijing: Science Education Publishing Company.

Statistical Communique on the National Economy and Social Development of Xinjiang in 2008.

The Eleventh Five-Year Plan for Xinjiang's Educational Development.

Wang, Mengkui. (2005). Some Important Issues on China's Middle and Long-Term Development from 2006 to 2020. China Development Press, pp64-81.

Yang, Yimin. (2006). Empirical Analysis on the Relationship between the Scale of Higher Education in a Region and Its Economic Development. Jiangsu Higher Education, (3).

Zhao, Hongbin, Liu, Niancai. et al. (2007). Research on the Distribution of Chinese Universities: the Perspective of Population and GDP. Higher Education Research, (1).

Table 1. The conversion of Chinese economic structure (Statistical Survey of China, 2005; Wang, 2005)

\begin{tabular}{|c|c|c|c|c|c|c|}
\hline & & 2000 & 2003 & 2004 & 2010 & 2020 \\
\hline \multicolumn{2}{|c|}{ GDP per capita } & 840 & 1094 & 1270 & 1742.2 & 3252.7 \\
\hline \multirow{3}{*}{$\begin{array}{l}\text { Industrial } \\
\text { structure } \\
(\%)\end{array}$} & $\begin{array}{l}\text { The primary } \\
\text { industry }\end{array}$ & 16.4 & 14.4 & 15.2 & 10.7 & 7.1 \\
\hline & $\begin{array}{l}\text { The } \\
\text { secondary } \\
\text { industry }\end{array}$ & 50.2 & 52.2 & 52.9 & 54.1 & 52.5 \\
\hline & $\begin{array}{l}\text { The tertiary } \\
\text { industry }\end{array}$ & 33.4 & 33.4 & 31.9 & 35.2 & 40.4 \\
\hline \multirow[t]{3}{*}{$\begin{array}{l}\text { Employment } \\
\text { structure (\%) }\end{array}$} & $\begin{array}{l}\text { The primary } \\
\text { industry }\end{array}$ & 50 & 49.1 & 46.9 & 41.0 & 34.2 \\
\hline & $\begin{array}{l}\text { The } \\
\text { secondary } \\
\text { industry }\end{array}$ & 22.5 & 21.6 & 22.5 & 24.2 & 22.4 \\
\hline & $\begin{array}{l}\text { The tertiary } \\
\text { industry }\end{array}$ & 27.5 & 29.3 & 30.6 & 34.9 & 43.4 \\
\hline
\end{tabular}


Table 2. Urbanization trends in China

\begin{tabular}{|l|l|l|l|l|l|}
\hline & 2000 & 2004 & 2005 & 2010 & 2020 \\
\hline National urbanization rate (\%) & 36.2 & 41.8 & 43.2 & 49.2 & 60.0 \\
\hline Western urbanization rate (\%) & 28.73 & & 34.20 & 40.12 & 52.48 \\
\hline
\end{tabular}

Table 3. Evaluation on the sources for China's economic growth (\%) (Statistical Survey of China, 2005; Wang, 2005)

\begin{tabular}{|l|l|l|l|l|l|l|l|}
\hline & GDP & \multicolumn{2}{|l|}{ Capital } & \multicolumn{2}{l|}{ Labor force } & \multicolumn{2}{l|}{ TFP } \\
\cline { 2 - 8 } & $\begin{array}{l}\text { Growth } \\
\text { rate }\end{array}$ & $\begin{array}{l}\text { Growth } \\
\text { rate }\end{array}$ & $\begin{array}{l}\text { Contribution } \\
\text { to economic } \\
\text { growth }\end{array}$ & $\begin{array}{l}\text { Growth } \\
\text { rate }\end{array}$ & $\begin{array}{l}\text { Contribution } \\
\text { to economic } \\
\text { growth }\end{array}$ & $\begin{array}{l}\text { Growth } \\
\text { rate }\end{array}$ & $\begin{array}{l}\text { Contribution } \\
\text { to economic } \\
\text { growth }\end{array}$ \\
\hline $1978-2003$ & 9.4 & 9.9 & 63.2 & 2.5 & 10.6 & 2.4 & 26.2 \\
\hline $2000-2003$ & 8.4 & 10.5 & 75.0 & 1.1 & 5.2 & 1.6 & 19.8 \\
\hline $2005-2010$ & 8.1 & 5.6 & & 0.4 & & 2.1 & \\
\hline $2010-2015$ & 7.5 & 5.0 & & 0.2 & & 2.3 & \\
\hline $2015-2020$ & 6.8 & 4.5 & & 0 & & 2.3 & \\
\hline
\end{tabular}

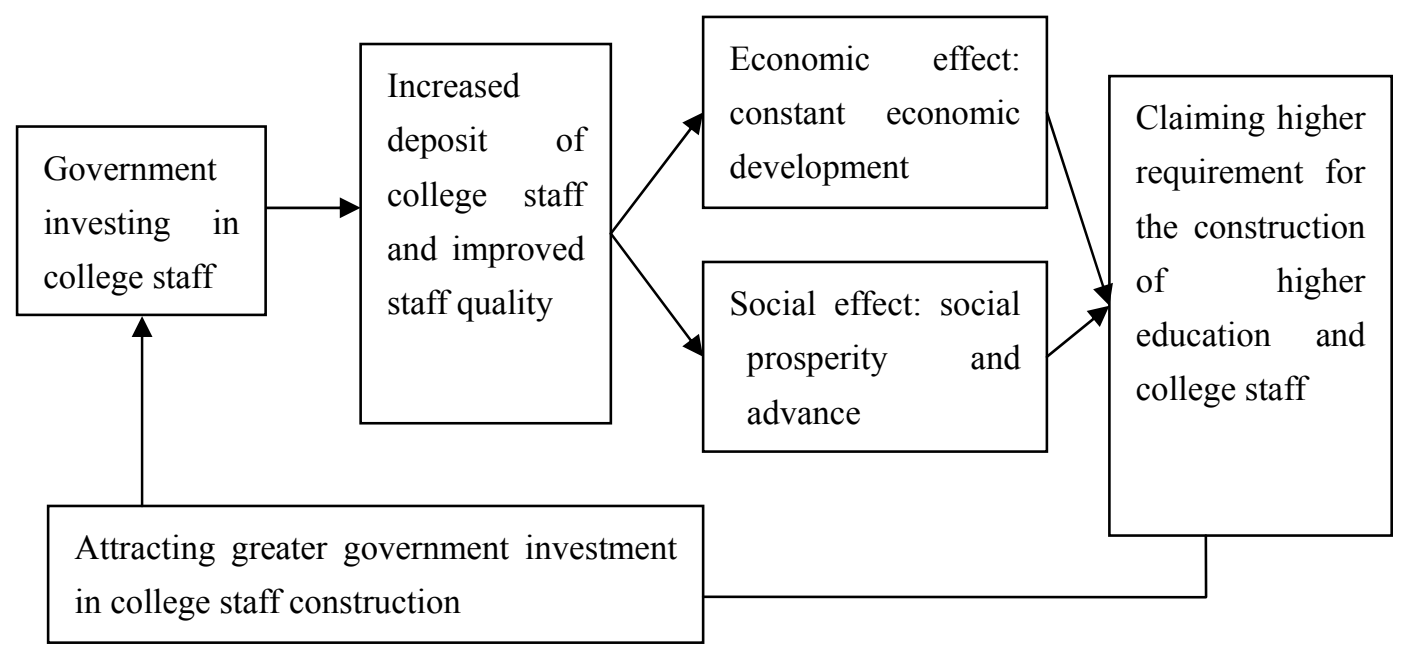

Figure 1. The Effect of Government Investment in College Staff 


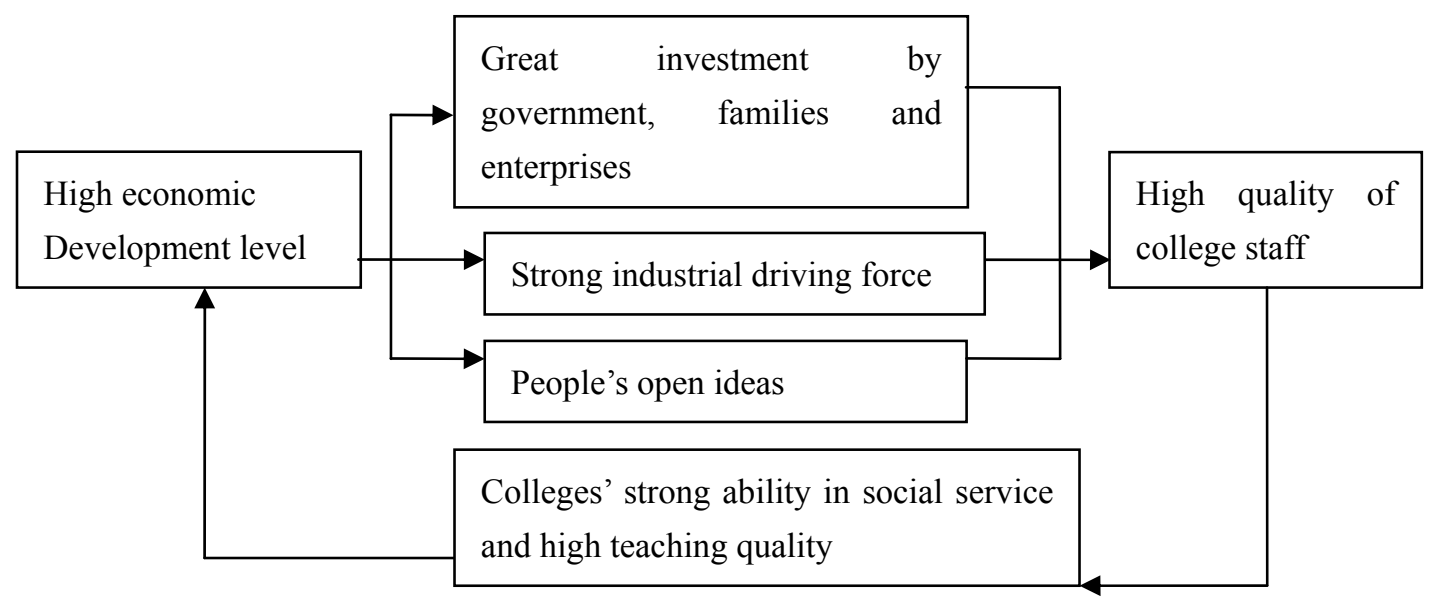

Figure 2. The virtuous Cycle of College Staff Quality and Economic Development

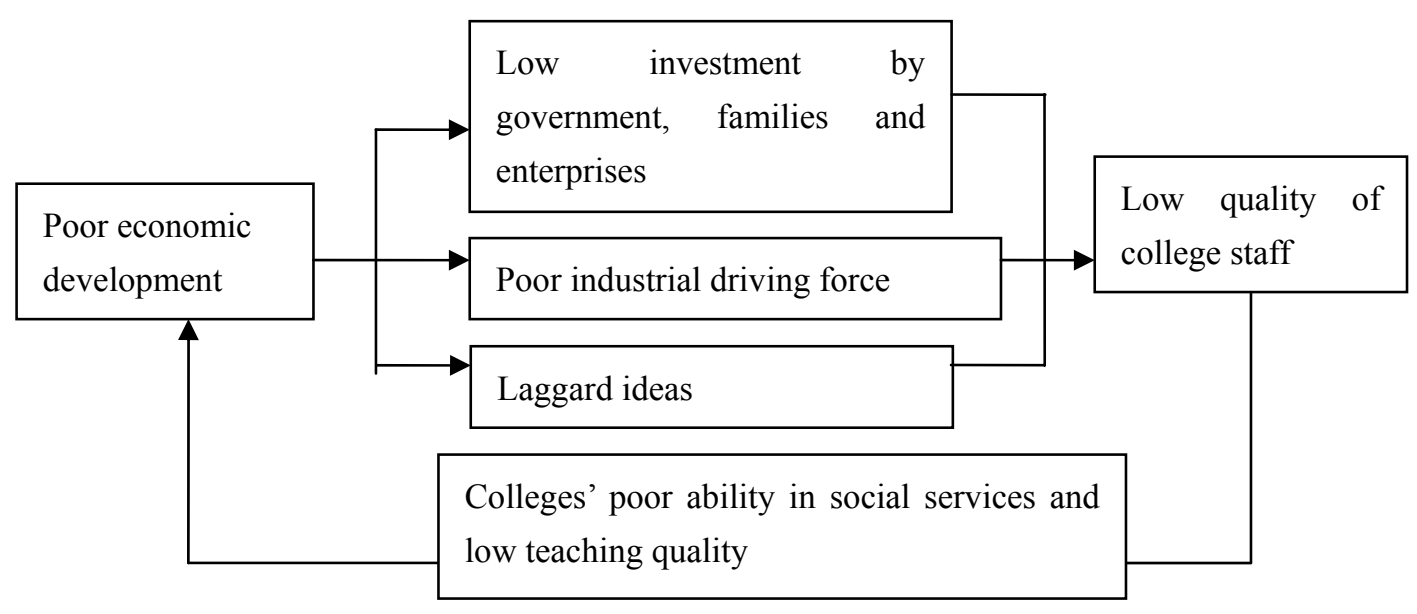

Figure 3. The Vicious Cycle of College Staff Quality and Economic Development 